\title{
ANALISIS PELUANG DAN TANTANGAN LEMBAGA KEUANGAN SYARIAH DALAM UPAYA MENINGKATKAN DAYA SAING TERHADAP LEMBAGA KEUANGAN KONVENSIONAL DI INDONESIA
}

\author{
Alvi Khikmatin ${ }^{1}$, Putri Setianingsih ${ }^{2}$ \\ 1,2)IAIN Pekalongan \\ 1alvikhik06@gmail.com, 2putrityani6@gmail.com
}

\begin{abstract}
Abstrak. Muslim senang dengan perkembangan Bank Syari'ah. Jika Bank Syari'ah di Indonesia dibandingkan dengan Bank Syariah di seluruh dunia, Indonesia adalah yang terbesar, terbesar dalam jumlah Bank Syari'ah, terbesar dalam jumlah pelanggan, DPS, pegawai bank, dan terbesar dalam jumlah universitas yang menawarkan program perbankan syari'ah. Namun sangat ironis kebanyakan Muslim meresponnya negatif. Kenyataan menunjukkan kepada kita bahwa pelanggan Muslim di Bank Syari'ah adalah lebih sedikit daripada pelanggan non-Muslim. Sebenarnya, Bank Syari'ah adalah bank berdasarkan prinsip-prinsip syariah dalam operasionalnya, dan memiliki karakteristik dan prinsip-prinsip yang berbeda dibandingkan dengan bank konvensional. Prinsipprinsip Bank syariah adalah 1). Menentang riba, 2). Menjual prioritas, 3). Saling menguntungkan dan bekerjasama, 4). Keadilan, dan 5). Bekerjasama meningkatkan prestasi. Dalam perspektif legalitas, bank syariah jelas berdasarkan hukum dalam aktivitas operasionalnya, yaitu (1) perundangundangan dan peraturan bank Indonesia, (2) Fatwa Dewan Syariah Nasional (DSN), (3) peraturan perundang-undangan konvensional yang lain. Sehingga bank syariah diijinkan dalam hukum Islam.
\end{abstract}

Kata Kunci. Lembaga Keuangan Syariah, Lembaga Keuangan Konvensional

Abstract. The muslim are in happiness with the development of Islamic bank. If Islamic bank in Indonesia compared with Islamic bank all part of the world, Indonesia is the biggest one, biggest in totality of Islamic bank, biggest in totality of Customer, DPS, banker and biggest in totality of university which offers Islamic bank program. However it is very ironic lot of muslim respond it negatively. The fact shows us that muslim customers are lower than non muslim customers of Islamic bank. Really Islamic bank is a bank based on shariate principles in operationalization and has different characteristics and principles it compared with conventional bank. Principles of Islamic bank are 1). Opposed to usury, 2). Sell and by priority, 3). Mutual helping and corporation, 4). Justice and, 5). Corporation increasing achievement. In legality perspective Islamic bank clearly based on low, in operational activities, those are (1). Constitution and regulation of Indonesia bank, (2). Fatwa of DSN (Dewan Syari'ah Nasional), (3). Other conventional constitutional regulation, so Islamic bank is permitted in Islamic low.

Kata Kunci. Islamic Financial Institutions, Conventional Financial Institutions 


\section{AL-IOTISHOD \\ Jurnal Ehonomi Suariah \\ Institut Agama Islam Sunan Kalijogo Malang \\ P-ISSN 2715-7725 E-ISSN 2721-9496 \\ Volume 3 Nomor 1 Juni 2021}

\section{PENDAHULUAN}

\section{A. Latar Belakang}

Lembaga keuangan adalah suatu usaha yang setiap kegiatannya berkaitan mengenia uang, seperti menghimpun dana atau uang , kemudian penyaluran dan atau jasa-jasa keuangan yang lainnya. Menurut Dewan Syariah Nasional (DSN) sendiri, Lembaga Keuangan Syariah adalah lembaga keuangan yang sudah mendapatkan izin dalam melakukan kegiatan operasionalnya sebagai lembaga keuangan untuk mengeluarkan produk dari keuangan syariah. ${ }^{1}$

Lembaga keuangan berkaitan erat dengan aktivitas ekonomi. Dengan adanya sistem perekonomian yang semakin terbuka ini, menjadikan setiap pelaku usaha bebas memasarkan produknya kemana saja. Melihat hal tersebut, tentunya akan menjadi peluang yang besar bagi pelaku usaha untuk meningkatkan dan memperbesar usahanya.

Semakin besar sebuah usaha semakin besar pula modal yang diperlukan. Oleh karena itu diperlukanya sebuah lembaga keuangan yang dapat memberikan solusi atau meminjamkan danaya. Terdapat dua lembaga keuangan yang ada di Indonesia yaitu lembaga keuangan berbasis syariah dan lembaga keuangan konvensional. Masyarakat bebas memilih lembaga keuangan yang akan digunakan dalam setiap aktivitas transaksinya dan diantara kedua lembaga keuangan tersebut memiliki keuanggulan masing-masing.

Pada masa sekarang Lembaga Keuangan Syariah semakin berkembang pesat. Hal ini terbukti dengan semakin banyaknya lembaga jasa keuangan syariah , layanan dan produk hingga semakin meningkatnya infrastrutur di Lembaga Keuangan Syariah. Salah satu peluang yang dapat menjadikan Lembaga Keuangan Syariahdi Indonesia semakin meningkat ialah karena masyarakat Indonesia yang sebagian besar beragama islam, mulai tumbuh kesadaran untuk menggunakan layanan jasa keuangan syariah yang sesuai dengan prinsip islam. Agar Lembaga Keuangan Syariah semakin dikenal di masyarakat dan dapat semakin berkembang maka diperlukan memanfaatkan peluang-peluang lain yang ada dengan maksimal

${ }^{1}$ Kautsar Riza Salman, Akuntansi Perbankan Syariah : Berbasis PSAK Syariah, (Jakarta : PT. Indeks, 2017), hlm. 40. 


\section{AL-IOTISHOD \\ Jurnal Ehonomi Suariah}

Institut Agama Islam Sunan Kalijogo Malang

P-ISSN 2715-7725 E-ISSN 2721-9496

Volume 3 Nomor 1 Juni 2021

Akan tetapi jika ada peluang maka akan adapula tantangan yang harus dihadapi agar Lembaga Keuangan Syariah semakin tumbuh berkembang. Mengingat sebelumnya masyarakat sudah lebih terbiasa dengan menggunakan transaksi keuangan secara konvensional. Hal ini tentunya menjadi tantangantantangan tersendiri bagi Lembaga Keuangan Syariah agar dapat bersaing dengan Lembaga Keuangan Konvensional sehingga dapat terus meningkatkan eksistansinya.

Oleh karena melihat peluang dan tantangan di Lembaga Keuangan Syariah yang ada di Indonesia penulis ingin malakukan penelitian mengenai "Analisis Peluang dan Tantangan Lembaga Keuangan Syariah Dalam Upaya Meningkatkan Daya Saing Terhadap Lembaga Keuangan Konvensional Di Indonesia"

\section{B. Tujuan dan Manfaat Penelitian}

Adapun tujuan yang ingin di capai dari penelitian ini yaitu untuk mengetahui bagaimana peluang Lembaga Keuangan Syariah dalam upaya meningkatkan daya saing terhadap lembaga keuangan konvensional serta untuk mengetahui bagaimana peluang Lembaga Keuangan Syariah dalam upaya meningkatkan daya saing terhadap lembaga keuangan konvensional. Sedangkan manfaat dari adanya penulisan ini diantaranya: secara teoritis, diharapkan dapat bermanfaat untuk memperkaya pengetahuan dan keilmuan mengenai berbagai peluang maupun tantangan lembaga keuangan syariah dalam menghadapi lembaga keuangan konvensional di Indonesia yang dapat digunakan sebagai bahan referensi untuk penulisan selanjutnya. Adapun secara praktis, penulisan ini bertujuan untuk masyarakat umum maupun dari pihak lembaga keuangan sendiri mengenai pengetahuan tentang lembaga keuangan yang ada di Indonesia dan bagaimana sistem operasianal didalamnya

\section{Metode Penelitian}

Metode penelitian yang digunakan dalam penulisan ini adalah metode kualitatif dengan pendekatan deskriptif analisis. Jenis penelitian ini menggunakan studi pustaka dengan sumber data diperoleh dari sumber sekunder baik berupa internet, buku, jurnal, publikasi ilmiah, dan sumber lain yang relevan. Penelitian ini bersifat deskkriptif kualitatif menjelaskan atau memaparkan hasil penelitian mengenai bagaimana peluang dan tantangan Lembaga Keuangan Syariah untuk meningkatkan daya saing terhadap Lembaga Keuangan Konvensional di Indonesia. 
Adapun teknik pengumpulan data yang digunakan dalam penelitian ini adalah menggunakan teknik metode studi pustaka, dengan mencari teori yang berhubungan dengan Lembaga Keuangan Syariah serta peluang dan tantanganya.

\section{PEMBAHASAN}

\section{A. Landasan Teori}

\section{1). Lembaga Keuangan Konvensional}

\section{a. Pengertian Lembaga Keuangan Konvensional}

Lembaga Keuangan adalah badan usaha yang memiliki aset utama yaitu berbentuk keuangan maupun tagihan-tagihan yang dapat berupa saham, obligasi, dan pinjaman. Lembaga keuangan adalah tempat transformasi atau perpindahan dana dari pihak yang mengalami kelebihan dana (surplus of funds)kepada pihak yang mengalami kekurangan dana (deficit of funds).

\section{b. Jenis-jenis Lembaga Keuangan Konvensional Di Indonesia}

- Bank Sentral (Central Bank)

Bank Sentral merupakan bank yang dimiliki oleh pemerintah yang memiliki tugas untuk menjaga, menagtur, serta memelihara kestabilan nilai mata uang negara Indonesia.

- Bank Umum (Comercial Bank)

Bank Umum merupakan suatu lembaga yang menjalankan usahanya secara konvensional dan kegiatannya memberikan jasa dalam lalu lintas pembayaran.

- Modal ventura

Modal ventura merupakan memiliki tugas yaitu melakukan usaha pembiayaan dalam bentuk penyertaan modal dalam suatu perusahaan yang menerima bantuan pembiayaan untuk jangka waktu tertentu.

- Anjak piutang

Anjak piutang merupakan badan usaha yang memiliki tugas untuk melakukan kegiatan pembiayaan dalam bentuk pembelian dan atau pengalihan, serta pengurusan piutang dan tagihan jangka pendek suatu perusahaan (debitur) dari transaksi perdagangan di dalam atau di luar negeri. 
- Asuransi

Asuransi adalah suatu bentuk perjanjian antara dua pihak atau lebih, dimana pihak penanggung mengikatkan diri kepada tertanggung, dengan menerima premi asuransi untuk memberikan penggantian kepada tertanggung karena kerugian, kerusakan, atau kehilangan keuntungan yang diharapkan.

- Dana pensiun

Dana pensiun merupakan suatu lembaga yang memiliki tugas untuk mengelola program pensiun yang tujuannya untuk memberikan kesejahteraan kepada karyawan di suatu perusahaan terutama mereka yang sudah pensiun.

- Pegadaian

Pegadaian merupakan lembaga yang memiliki tugas untuk memberikan pinjaman kepada masyarakat dengan menahan barang tersebut sebagai untuk dijadikan sebagai jaminannya.

- Pasar Modal

Pasar Modal adalah pasar yang dalam kegiatan operasionalnya memperjualbelikan berbagai instrumen keuangan (sekuritas) jangka panjang, baik itu berbentuk utang ataupun berbentuk modal sendiri yang sudah diterbitkan oleh perusahaan swasta.

- Pasar uang

Pasar Uang adalah sarana yang didalamnya menyediakan pembiayaan jangka pendek (kurang dari 1 tahun), pasar uang ini tidak mempunyai tempat fisik seperti halnya pasar modal.

- Reksadana

Reksadana merupakan lembaga keuangan yang digunakan untuk menghimpun dana dari masyarakat pemodal dan kemudian diinvestasikan dalam portofolio efek oleh manajer investasi. Portofolio efek ini seperti obligasi, saham, deposito, instrument pasar uang, uang kas dan lain sebagainya. ${ }^{2}$

${ }^{2}$ Roifatus Syauqoti Mohammad Ghozali, "Analisis Sistem Lembaga Keuangan Syariah dan Lembaga Keuangan Konvensional”, Iqtishoduna Vol. 14 No. 1 Tahun 2018 . 


\section{2). Lembaga Keuangan Syariah}

\section{a. Pengertian Lembaga Keuangan Syariah}

Lembaga Keuangan Syari'ah merupakan lembaga keuangan yang memiliki prinsip operasi berdasarkan kepada prinsip Syariah Islamiah. Operasional harus terhindar dari unsur dari riba, gharar dan maisir. Karena hal tersebut sangat diharamkan dan sudah diterangkan dalam Al-Quran dan AlHadist. Adapun tujuan utama didirikannya lembaga keuangan syariah yaitu untuk menunaikan perintah Allah SWT di bidang ekonomi, muamalah sekaligus membebaskan masyarakat Islam dari kegiatan yang dilarang oleh Islam. Untuk melaksanakannya, tidak sepenuhnya hanya dilakukan oleh lembaga keuangan syariah saja, melainkan merupakan tugas seluruh masyarakat.

Lembaga keuangan syariah baik itu bank maupun non-bank dalam melaksanakan kegiatan operasionalnya selalu diawasi oleh sebuah lembaga yang dinamakan dengan Dewan Pengawasan Syariah. Dari pengertian ini dapat dijelaskan bahwa lembaga keuangan syariah adalah suatu lembaga yang mencakup segala aspek keuangan baik itu tentang persoalan perbankan ataupun kerjasama pembiayaan, keamanan dan asuransi perusahaan, dan lains ebagainya yang berlangsung di luar konteks perbankan. ${ }^{3}$

Untuk unsur kesesuaian Lembaga Keuangan Syariah dengan syariah Islam secara tersentralisasi diatur oleh DSN, yang diwujudkannya dalam berbagai fatwa yang dikeluarkan. Sedangkan unsur legalitas operasi sebagai lembaga keuangan sendiri diatur oleh berbagai instansi yang memiliki kewenangan mengeluarkan izin operasi. Instansi tersebut antara lain sebagai berikut :

- Bank Indonesia yang memiliki funsi sebagai institusi dan memiliki kewenangan untuk mengatur dan mengawasi Bank Perkreditan Rakyat dan Bank Umum.

- Departemen Keuangan yang memiliki fungsi sebagai institusi dan memiliki kewenangan untuk mengatur dan mengawasi koperasi.

${ }^{3}$ RizkiDianMensari, Ahmad Dzikra, "Islam dan Lembaga Keuangan Syariah", AL-INTAJVol. 3, No. 1, Maret 2017Fakultas Ekoomi dan Bisnis IslamP-ISSN : 2476-8774/E-ISS : 2621-668X 


\section{AL-IOTISHOD \\ Jurnal Ehonomi Suariah \\ Institut Agama Islam Sunan Kalijogo Malang \\ P-ISSN 2715-7725 E-ISSN 2721-9496 \\ Volume 3 Nomor 1 Juni 2021}

- Kantor Menteri Koperasi yang memiliki fungsi sebagai institusi dan memilii kewenangna untuk mengatur dan mengawasi koperasi.

\section{b. Operasional Lembaga Keuangan Syariah}

Prinsip operasional yang ada di Lembaga Keuangan Syariah ialah:

- Keadilan, merupakan prinsip berbagi atas keuntungan penjualan yang sebenar-benarnya berdasarkan dari konstribusi serta resiko dari setiap pihak.

- Kemitraan, ialah prinsip dimana kesetaraan antara masing-masing pihak yang terlibat di dalam kerjasama tersebut. Posisi dari nasabah investor (penyimpanan dana), serta penggunaan dana, dan lembaga keuangan itu itu, sejajar sebagai mitra usaha dan saling bersinergi agar dapat memperoleh sebuah keuntungan.

- Transparansi, merupakan Lembaga Keuangan Syariah yang mana harus memberikan sebuah laporan keuangan berkesinambungan kepada pihak nasabah investor atau setiap pihak yang terlibat didalamnya supaya dapat mengetahui kondisi nyata dari dana dan harus dilakukan secara terbuka.

- Universal, ialah sebuah prinsip keharusan dari Lembaga Keuangan Syariah untuk memberikan agama, ras,suku serta golongan masyarakat dalam pemberian layanan harus sesuai prinsip islam.

Beberapa hal yang harus diperhatikan dalam LKS ialah: .

- Pembayaran sebuah pinjaman harus dengan nilai yang berbeda dari nilai pinjaman dimana penentuan nila sebelumnya tidak diperkenankan

- Pemberi dana harus terlibat berbagi kerugian dan keuntungan sebagai dampak dari keluaran usaha yang meminjam dana .

- Islam melarang "menghasilkan uang dari uang". Uang merupakan media untuk pertukaran bukan komoditas karena uang tidak memiliki nilai intrinsik.

- Unsur gharar (ketidakpastian,spekulasi) tidak diperkenankan. Masing-masing pihak harus mengetahui dengan pasti hasil yang akan mereka dapatkandari sebuah transaksi. 
- Tidak diperkenankan melakukan investasi pada hal yang diilarang islam. ${ }^{4}$

\section{c. Jenis-jenis Lembaga Keuangan Syariah di Indonesia.}

- Baitulmal Wat Tamwil (BMT)

BMT merupakan lembaga keuangan syariah yang memiliki tugas menghimpun sekaligus menyalurkan dana kepada para anggota. BMT ini tidak menuntut untuk mendapatkan keuntungan. Adapun contoh penerapab dari lembaga keuangan ini diantaranya adalah penghimpunan dan penyaluran infak, zakat, serta sedekah.

- Asuransi Syariah

Asuransi syariah merupakan usaha tolong-menolong sekaligus saling melindungi antar peserta dengan penerapan operasional yang menggunakan prinsip hukum syariat Islam.

- Pasar Modal Syariah

Pasar Modal merupakan tempat yang digunakan untuk menerbitkan surat berharga perusahaan, baik itu dalam bentuk saham ataupun dalam bentuk obligasi untuk memperoleh dana dari para investor (penanam modal).

- Reksadana Syariah

Reksadana Syariah merupakan perusahaan sekuritas yang dalam kegiatan operasionalnya hanya memfasilitasi mereka para investor dalam menginvestasikan dananya. Karena terdapat larangan bagi Bank Syariah untuk membeli saham secara langsung di Pasar Modal, maka Bank Syariah tidak berhubungan dengan Reksadana dalam hal pembelian saham

- Pegadaian Syariah (Ar-Rahnu)

Ar-Rahnu adalah lembaga pegadaian yang dalam sistem operasioanalnya dilakukan sesuai dengan prinsip maupun aturan Syariah Islam. Di Indonesia sendiri, dalam pembentukannya Pegadaian Syariah diprakarsai oleh BMI (Bank Muamalat Indonesia).

- LAZ (Lembaga Amil Zakat) dan BAZ (Badan Amil Zakat)

\footnotetext{
${ }^{4}$ Nurul Huda dan Mohammad Heykal, Lembaga Keuangan Islam: Tinjauan Teoritis danPraktis, (Jakarta: Kencana Prenada Media Grup,2010), hlm.38-39.
} 


\section{Institut Agama Islam Sunan Kalijogo Malang}

Dalam fungsi kegiatannya, bank syariah juga dapat bergerak dalam bidang sosial yaitu dengan cara mendirikan lembaga baitulmal yang memiliki tujuan untuk menerima sumber dana yang berasal dari zakat, infak, hibah, sedekah, dan dana sosial lainnya.

- Koperasi Syariah

Koperasi syariah merupakan koperasi yang semua kegiatan maupun usahanya bergerak di dalam bidang simpanan pokok, pembiayann yang sesuai dengan pola bagi hasil dan investasi.

- Pasar Uang Syariah

Pasar uang syariah adalah suatu pasar yang didalamnya terjadi perdagangan surat-surat berharga syariah dengan jangka waktu pendek (kurang dari 1 tahun).

- Dana Pensiun Syariah

Tujuan dari dibentuknya Dana pensiun syariah ini adalah untuk memelihara kesinambungan penghasilan pada waktu hari tua, yaitu ketika yang bersangkutan tersebut sudah tidak mampu lagi untuk bekerja.

- Leasing Syariah

Leasing Syariah merupakan lembaga yang sangat mendukung masyarakat dalam bidang transaksi sewa-menyewa, terlebih kepada transaksi sewamenyewa yang memiliki prinsip maupun konsep ijarah (sewa-menyewa dengan sistem syariah).

- Modal Ventura Syariah

Modal Ventura Syariah merupakan suatu lembaga keuangan yang bergerak dalam bidang permodalan yang melibatkan berbagai pihak yang samsama ikut dalam kontribus idalam membangun usaha yang agar menjadi lebih maju dan besar.

- Anjak Piutang Syariah 


\section{AL-1QTISHOD \\ Jurnal Ehonomi Suariah}

Institut Agama Islam Sunan Kalijogo Malang

P-ISSN 2715-7725 E-ISSN 2721-9496

Volume 3 Nomor 1 Juni 2021

Anjak Piutang Syariah merupakan lembaga yang memiliki fungsi untuk mengambil alih pembayaran kredit pada suatu perusahaan, khususnya perusahaanyang berhubungan dengan kredit bermasalah. ${ }^{5}$

\section{Hasil Pembahasan}

\section{Peluang}

Istilah lain dari peluang adalah sebuah kesempatan. Peluang merupakan adanya sebuah kesempatan atau harapan yang dapat kita wujudkan melalui cara-cara tertentu untuk terpenuhinya sebuah tujuan. Perkembangan Lembaga Keuangan Syariah di Indonesia semakin meningkat. Ditengah persaingan dengan Lembaga Keuangan Konvensional, Lembaga Keuangan Syarian sendiri memiliki sebuah peluang yang berpotensi menjanjikan seperti :

a. Jumlah penduduk di Indonesia bermayoritas islam

Di Indonesia 85\% mayoritas penduduknya beragama islam, hal ini menjadi peluang tersendiri agar dapat meningkatkan perkembangan Lembaga Keuangan Syariah yang ada di Indonesia. ${ }^{6}$ Dengan jumlah penduduk muslim yang banyak ini harapanya Lembaga Keuangan Syariah dapat terus melakukan sebuah inovasi-inovasi terbaru sehingga meningkatkan daya tarik untuk membuat masyarakat muslim menggunakan Lembaga Keuangan Syariah dalam melakukan setiap transaksi.

b. Keuanggulan dari Lembaga Keuangan Syariah

Lembaga Keuangan Syariah dalam menjalankan aktivitasnya, selalu memegang teguh prinsip-prinsip syriah yang sesuai dengan islam. Prinsip tersebut diantarana adalah prinsip keadilan, transparan dan kemitraan. Dengan adanya prinsip tersebut masyarakat akan merasa lebih percaya dalam meggunakan Lembaga Keuangan Syariah.

Dari segi akad dan legalitas, akad yang dilakukan dalam bank syariah memiliki konsep duniawi sekagigur ukrawi. Dimana dalam akad ini tidak hanya keuntungan duniawainya saja yang dikedepankan namun dalam akad tersebut juga berdasarkan ketentuan-ketentuan syraiah yang sesuai dengan islam. Dalam transaksi di Lembaga

${ }^{5}$ Faisal, 2017, Lembaga-lembaga Keuangan Syariah di Indonesia, https://www.ekituntas.com/2019/03/lembaga-lembaga-keuangan-syariah-di.html, Diakses pada tanggal 12 Januari pukul 12:57 WIB

${ }^{6}$ Dayna Oklin Ndruru, Peluang Dan Tantanagn Lembaga Keuangan Syariah Di Bengkulu, (Bengkulu : IAIN Bengkulu, 2019) , HIm. 18. 


\section{AL-IOTISHOD \\ Jurnal Ehonomi รщагіah \\ Institut Agama Islam Sunan Kalijogo Malang \\ P-ISSN 2715-7725 E-ISSN 2721-9496 \\ Volume 3 Nomor 1 Juni 2021}

Keuangan Syariah apabila terdpat pihak yang melanggar atutan terdapat duan konsekuensi yang akan diterima yaitu hukum didunia dan hukum diakhirat.

Pada Lembaga Keuangan Syariah tidak terdapat bunga bank yng dapat menjadikan riba melainkan menggunakan sistem bagi hasil atau profit sharing dan adil. Jadi dalam Lembaga Keuangan Syariah tidak semata-mata hanya mengejar keuntungan yang besar saja berbeda dengan Lembaga Keuangan Konvesial keuntungan yang dikejar sebanyak-banyaknya tidak peduli meskipun riba.

Jika terdapat perselisihan yang terjadi ntara pihak nasabah dan bank maka cara penyelesainya tidak di Pengadilan negeri seperti yang dilakukan pada bank konvensional melainkan di Badan Arbitrase Syariah Nasional (BASYARNAS). Dalam menyelesaikan perselisihan atau sengketa yang terjadi di Lembaga Keuangan Syariah penyelesaian BASYARNAS mengacu pada materi hukum-hukum syariah, sesuai dengan Pasal 55 ayat (2) UU No. 21 Tahun 2008 yang berbunyi:" Dalam hal para pihak telah memperjanjikan penyelesaian sengketa selain sebagaimana dimaksud pada ayat (1), penyelesain sengketa dilakukan sesuai dengan isi akad". Maka jika dalam akad dituangkan bahwa penyelesaian sengketa melalui arbitrase, hal ini dimungkinkan terjadi sesuai dengan kesepakatan para pihak yaitu bank dan nasabah. Selain itu dengan amandemen Undang-Undang Peradilan Agama, maka penyelesaian sengketa dapat diselesaikan di Pengadilan Agama.

Hal ini dimungkinkan karena undang-undang tersebut secara eksplisit dalam Pasal 49 menyebutkan bahwa Pengadilan Agama dapat menyelesaiakan sengketa ekonomi Islam. Hal ini juga dituangkan dalam Pasal 55 ayat (1) UU No. 21 Tahun 2008 yang berbunyi: "Penyelesaian sengketa Perbankan Syariah dilakukan oleh pengadilan dalam lingkungan Peradilan Agama".

Terdapat struktur organisasi di Lembaga Keuangan Syariah yang dalam pelaksanaanya berfungsi untuk mengawasi jalanya lembaga keuangan tersebut sehingga apabia terdapat lembaga yang mneyeleweng aturan maka akan segera diketahui dan diberikan sanksi. Struktur organisasi tersebut seperti Dewan Pengawas Syariah (DPS) dan Dewan Syariah Nasional (DSN).

c. Adanya dukungan dari pemerintah 


\section{AL-1QTISHOD \\ Jurnal Ehonomi Suariah}

Institut Agama Islam Sunan Kalijogo Malang

P-ISSN 2715-7725 E-ISSN 2721-9496

Volume 3 Nomor 1 Juni 2021

Pemerintah mengeluarkan undang-undang sebagi bentuk dukunganya terhadap Lembaga Keuangan Syariah sehingga dapat menjadikan kekuatan . Adapun undang-undang yang sudah dikeluarkan adalah UU No 7 tahun 1992, UU No 10 tahun 1998, dan UU No 21 tahun 2008 tentang perankan syariah. Selain itu DSN-MUI mengeluarkan 119 fatwa tentang ekonomi Syariah. ${ }^{7}$

d. Semakin tumbuh dan berkembangnya lembaga-lembaga keislaman

Adanya partai-partai isam yang bermunculan setelah masa era reformasi memiliki pengaruh terhadap kehidupan nasional. Terdapat kebijakan-kebijakan yang dikeluarkan oleh politisi muslim dan dapat mendukung kemajuan lembaga keuangan syariah. Di Indonesia juga semakin banyak berdiri sekolah-sekolah yang berbasis islami, baik dari SD,SMP,SMA hingga Perguruan Tinggi yang dapat menciptakan seorang kader ekonom yang berbasis islami.

\section{Tantangan}

Tantangan merupakan salah satu bentuk motivasi agar dapat mencapaian target. Tantangan ialah objek atau hal yang dapat membangkitkan tekadagar kemampuan dapat ditingkatkan sehingga dapat mengatasi sebuah masalah dan bekerja lebih giat lagi. ${ }^{8}$

a. Perlunya pengembangan kelembagaan.

Kelembagaan yang terdapat di Lembaga Keuangan Syariah belum sepenuhnya efisien dan kompetitif sehingga belum mapan. Terdapat masih rendahnya penggunaan teknologi, kurangnya dukungan dari pemodalan dan jaringan yang kurang luas, dan kapasitas dari SDM yang ada masih tidakmerata.

b. Kurangnya sosialisasi dan promosi

Masih banyak masyarakat yang kurang memahami mengenai Lembaga Keuangan Syariah, hal ini menjadi tantangan tersendiri untuk kedepanya bagaimana caranya agar masyarakat tahu dan mengerti apa itu Lembaga Keuangan Syariah. Jika sudah mengetahui tentang Lembaga Keuangan Syariah selanjutnya memikirkan bagaimana cara agar masyarakat paham, dari yang telah paham terkadang ada yang

${ }^{7}$ Yayat Rahmat Hidayat, "Analisis Peluang Dan Tantanagn Lembaga Keuangan Syariah Untuk Meningkatkan Daya Saing Menghadapi Masyarakat Ekonomi Asean", Jurnal Ekonomi dan Keuangan Syariah Vol.2, No.2 Juli 2018, HIm. 176.

${ }^{8}$ Apaarti.com dikutip dari https://www.apaarti.com/tantangan.html, Diakses pada tanggal 12 Januari 2021 pukul 20:31 WIB. 


\section{AL-IOTISHOD \\ Jurnal Ehonomi Suariah \\ Institut Agama Islam Sunan Kalijogo Malang \\ P-ISSN 2715-7725 E-ISSN 2721-9496 \\ Volume 3 Nomor 1 Juni 2021}

belum percaya, dan dari yang sudah percaya namun masih kurangnya partisipasi. Dan dari masalah tersebut Lembaga Keuangan Syariah hars mencari solusi untuk mengahadapinya.

Terkadang masyarakat lebih memahai tetang lembaga keuangan konvensional karena lembaga tersebut lebih sering didengar dan tidak asing di telinga masyarakat. Oleh karena itu diperlukan sebuah promosi dan sosialisasi yang dapat menarik perhatian asyarakat dapt melalui media seperti televisi, radio dan dapat pula melalui media koran maupun majalah.Dengan adanya teknologi yang semakin berkembang sebaiknya memanfaatkan media internet yang dapat diakses kapan saja.

c. Kuranganya perluasan pada jaringan kantor

Lembaga Keuangan Syariah yang ada di Indonesia masih sediki belum sebanyak lembaga Keuangan Konvensional. Terutama pada di masyarakat pedesaan masih suli menemukan Lembaga Keuangan Syariah karena yang dominan adalah konvensional.

d. Peningkatan SDM.

Sumber Daya Manusia yang amanah, jujur profesional dan berkualitas masih sedikit yang ada. Padahal komponen tersebut harus ada di Lembaga Keuangan Syariah sehingga pegawai-pegawainya dapat diandalkan dan dapat melakukan tugasnya sesuai syariah, namun pada kenyataanya sangat jarang ditemukan, sumber daya manusianya masih banyak keluaran dari didikan konvensioanl. Pegawai di Lembaga Keuangan Syariah harus memahami tentang fiqih dan cara-cara menyelesaiakan permasalahan di Lembaga Keuangan Syariah sesuai prinsip-prinsip islami. Masih terbatasnya jenis dan akses terhadap produk dan layanan keuangan syariah, untuk memenuhi kebutuhan masyarakat.

e. Perlunya peningkatan modal

Untuk mengembangkan Lembaga Keuangan Syariah perlu adanya peningkatan modal yang ada agar dapat melakukan pembiayaan perluasan dan melakukan pendanaan bagi para pelaku usaha. Pemegang saham atau stake holder pada Lembaga Keuangan Syariah perlu menambah jumlah modalnya agar risk taking capacity-nya dapat meningkat. Karena setiap aktivitas pendanaan di Lembaga Keuangan Syariah sangat dipengaruhi oleh besar kecilnya modal yang ada. 


\section{Kesimpulan}

Menurut Dewan Syariah Nasional (DSN) Lembaga Keuangan Syariah merupakan sebuah lembaga keuangan yang mendapatkan ixin untuk melakukan kegiatan operasional sebagai lembaga keuangan guna mengeluarkan produk dari keuangan syariah. Peluang Lembag Keuangan Syariah adalah, jumlah penduduk di Indonesia bermayoritas islam, keunggulan dari lembaga keuangan syariah sendiri, adanya dukungan dari pmerintah, semakin tumbuh dan berkembangnya lembaga keislam

Selain memiliki peluang, Lembaga Keuangan Syariah juga memiliki tantangan untuk menghadapi persaingan terhadap Lembaga Keuangan Konvensional. Adapun tantanganya adalah, perlunya pengembangan kelembagaan, kurangnya sosialisasi dan promosi, kurangnya perluasan pada jaringan kantor, perlunya peningkatan sumber daya manusia, perlunya peningkatan modal. 


\section{DAFTAR PUSTAKA}

Apaarti.com dikutip dari https://www.apaarti.com/tantangan.html. Diakses pada tanggal 12 Januari 2021 pukul 20:31 WIB.

Faisal, 2017. "Lembaga-lembaga Keuangan Syariah di Indonesia". https://www.ekituntas.com/2019/03/lembaga-lembaga-keuangan-syariah-di.html, Diakses pada tanggal 12 Januari pukul 12:57 WIB.

Ghozali , Roifatus Syauqoti Mohammad . 2018. "Analisis Sistem Lembaga Keuangan Syariah dan Lembaga Keuangan Konvensional", Iqtishoduna Vol. 14 No. 1 Tahun 2018.

Huda, Nurul ,Mohammad Heykal. 2010. Lembaga Keuangan Islam: Tinjauan Teoritis danPraktis. Jakarta: Kencana Prenada Media Grup.

Hidayat, Yayat Rahmat . 2018. “ Analisis Peluang Dan Tantanagn Lembaga Keuangan Syariah Untuk Meningkatkan Daya Saing Menghadapi Masyarakat Ekonomi Asean", Jurnal Ekonomi dan Keuangan Syariah Vol.2, No.2 ,Hlm. 176.

Mensari, Dian, Ahmad Dzikra, "Islam dan Lembaga Keuangan Syariah", ALINTAJVol. 3, No. 1, Maret 2017Fakultas Ekoomi dan Bisnis IslamP-ISSN : 24768774/E-ISS : 2621-668X

Ndruru, Dayna Oklin Ndruru. 2019. Peluang Dan Tantanagn Lembaga Keuangan Syariah Di Bengkulu, Bengkulu : IAIN Bengkulu.

Salman, Kautsar Riza. 2017. Akuntansi Perbankan Syariah : Berbasis PSAK Syariah. Jakarta : PT. Indeks. 